\title{
THE IMPORTANCE OF PSYCHOLOGICAL AND NUTRITIONAL FOLLOW-UP AFTER BARIATRIC SURGERY: LITERATURE REVIEW
}

\section{ORIGINAL ARTICLE}

DENDASCK, Carla Viana'1, SANTOS, Rogério Bongestab dos², SANTOS, Vitor Maia ${ }^{3}$, ANDRADE, Tadeu Uggere de ${ }^{4}$, PFLUG, Adriano Ribeiro Meyer ${ }^{5}$

\section{DENDASCK, Carla Viana. Et al. The importance of psychological and nutritional} follow-up after bariatric surgery: Literature review. Revista Científica Multidisciplinar Núcleo do Conhecimento. Year. 06, Ed. 10, Vol. 01, pp. 20-44. October 2021. ISSN: 2448-0959, Access link: https://www.nucleodoconhecimento.com.br/psychology/after-bariatric, DOI: 10.32749/nucleodoconhecimento.com.br/psychology/after-bariatric

\footnotetext{
${ }^{1}$ Theologian, PhD in Clinical Psychoanalysis. She has been working for 15 years with Scientific Methodology (Research Method) in Scientific Production Guidance for Masters and Doctoral Students. Specialist in Market Research and Health Research. Doctoral Student in Communication and Semiotics (PUC SP).

${ }^{2}$ Graduated in Medicine from the School of Science of Santa Casa de Misericórdia de Vitória - EMESCAM. Medical residency in general surgery at Hospital Santa Casa de Misericórdia de Vitória (HSCMV). Postgraduate in Nutritional Therapy at EMESCAM. Postgraduate in Nutrology from the Faculty of Medical Sciences of Santa Casa de Misericórdia of São Paulo (FCMSCM-SP/ABRAN). Specialist in Nutrology by the Brazilian Association of Nutrology (ABRAN). Specialist in Nutritional Therapy by the Brazilian Society of Parenteral and Enteral Nutrition (SBNPE/BRASPEN).

${ }^{3}$ Psychiatrist. Specialist in Psychiatry and Forensic Psychiatry by the Brazilian Association of Psychiatry (ABP). Doctor at the Ministry of Economy (ME). Qualified Master's Student in Pharmaceutical Sciences at the University of Vila Velha (UVV). Deputy Secretary Director of the Espírito Santo Psychiatric Association (APES). Secretary of the ABP Labor Psychiatry Commission. Professor in the Postgraduate Course in Psychiatry at the University of Vila Velha (UVV). Postgraduate degree in Occupational Medicine and postgraduate degree in Medical Expertise.

${ }^{4}$ Doctorate in Physiological Sciences - Federal University of Espírito Santo, UFES. Master in International Management - Steinbeis University Berlin, STW-SIBE. Master's Degree in Physiological Sciences - Federal University of Espírito Santo, UFES. Specialization in Functional Gastronomy - São Paulo Method College, FAMESP. Graduation in Pharmacy - Faculty of Pharmacy and Biochemistry of Espírito Santo, FAFABES. ${ }^{5}$ Doctor by FMUSP. Graduated in Medicine from the Faculty of Medicine of the University of São Paulo (FMUSP). Medical Residency in General Surgery and Advanced General Surgery at Hospital das Clinicas, Faculty of Medicine, University of São Paulo (HC-FMUSP). General Surgeon by the Brazilian College of Surgeons (CBC), Digestive System Surgeon by the Brazilian College of Digestive Surgery (CBCD). Bariatric Surgery (SBCBM) Assistant Physician of the Surgical Clinic Division III of the Central Institute of Hospital das Clínicas at FMUSP. RC: 98479
} 


\section{SUMMARY}

Obesity is a multifactorial chronic disease. The patient may present several clinical conditions associated with it. The clinical picture is complex, which can hinder the use of conventional treatments and methods. Bariatric surgery is an effective long-term treatment for this condition. Based on a literature review, the article aims to discuss the importance of post-bariatric psychological and nutritional follow-up. The fundamental question that underpits this study is: how can typical strategies in the postoperative period contribute to the individual undergoing surgery to give greater importance to his diet and mental health? The most effective treatment strategy has been bariatric surgery, however, the multidisciplinary evaluation that scores the patient's biological, social, and psychological status is fundamental, since psychopathological changes are common to obese individuals. Although bariatric surgery contributes to the improvement in the quality of life of patients, there needs to be greater attention to postoperative treatment. These individuals should be encouraged to continue with nutritional and psychological follow-up in the postoperative period, so that it is possible to prevent possible complications in the medium and long term.

Keywords: Obesity, Mental Health, Nutritional Monitoring, Bariatric.

\section{INTRODUCTION}

Obesity is a rising epidemic, and thus facilitates the development of comorbidities, such as diabetes and systemic arterial hypertension (RODRIGUES et al., 2017). This reaches global scales, about two billion people are obese or overweight. In 2008, it was estimated that about $43 \%$ of the adult population was obese, however, this number increased, reaching 54\% in 2015 (RODRIGUES et al., 2017). In Brazil, it was identified that, according to data from the Surveillance System of Risk and Protective Factors for Chronic Diseases by Telephone Survey, $53 \%$ of the adult population was considered overweight and $18.9 \%$ obese (BRASIL, 2017). With the increase in obesity, the number of bariatric surgeries consequently increased, as pointed out by the Brazilian Society of Bariatric and Metabolic Surgery (SBCBM, 2017). Brazil is the second country in the RC: 98479 
world in number of bariatric surgeries performed annually. Compared to 2015, there was a $7.5 \%$ increase in surgeries performed (SBCBM, 2017). Weight loss after surgery reflects a significant improvement in comorbidities, such as diabetes, dyslipidemia, hypertension and sleep apnea (BUCHWALD et al., 2004). However, it should be emphasized that surgical treatment is only a part related to the integral treatment of obesity, and nutritional and psychological follow-up after surgery is of fundamental importance. Therefore, one should invest in strategies to promote health and longitudinal clinical care (BRASIL, 2017). The patient who aims to perform the operation should fit some requirements, regardless of the surgical technique, such as BMl above $40 \mathrm{~kg} / \mathrm{m}^{2}$ or BMI above $35 \mathrm{~kg} / \mathrm{m}^{2}$ in the presence of comorbidities related to overweight (SBCBM, 2006). The list of comorbidities was expanded and a larger portion of the population was contemplated (BRASIL, 2017).

Every patient undergoing this type of surgery should undergo multidisciplinary followup. The objective is the evaluation, orientation and zeal for the team-patient relationship, as this is a way to promote the efficacy of treatment in the postoperative period (GORDON; KAIO; SALLET, 2011). The nutritionist plays a vital role in the pre and postoperative periods. Nutritional counseling in the preoperative period is intrinsically related to the increase in the potential for success in the postoperative period (CRUZ, 2004). A study related to weight recurrence concluded that $39 \%$ of the operated patients had weight gain (especially after 12 months of surgery). Among the factors that raised the problem is the low attendance to nutritional consultations in the preoperative period, which culminated in weight recurrence (BARDAL; CECATTO; MEZZOMO, 2016). Individuals who go through a process of nutritional education and counseling have better results.

Psychological and nutritional counseling should be prior to and after surgery. Regurgitation that usually affects patients who do not have the correct chewing habit is common to patients who do not undergo any type of multidisciplinary follow-up (COOPER et al., 1999). However, there is a high dropout in postoperative nutritional follow-up, which can lead to metabolic complications and weight recurrence (MENEGOTTO et al., 2013). Due to these reasons, the adjustment in feeding in the

RC: 98479

Access link: https://www.nucleodoconhecimento.com.br/psychology/after-bariatric 
preoperative period is of fundamental importance, because, thus, the new eating habits posed by the demands of the postoperative period will be more conducive to being put into practice (RODRIGUES et al., 2017). Lifelong adjustments that include eating behavior and physical activities are necessary for successful weight loss and to prevent long-term complications (COSTA, 2013).

In the preoperative nutritional assessment, in addition to complete nutritional anamnesis, food intake, laboratory tests, diagnosis of comorbidities and weight history are performed. It is valued for the correction of nutritional deficiencies frequently identified. Obese patients sometimes undergo multiple restrictive diets, and thus can be considered as a malnourished individual (DOLNE; SOUZA; MATTE, 2020). However, other issues pertaining to surgery should be evaluated, such as the availability for change and evaluation of general knowledge about nutrition and the surgery itself (AILLS et al., 2008). Such information allows the professional to identify possible barriers that may interfere with weight loss or result in negative postoperative conditions, such as alcohol and other drug abuse. In addition, the patient should be prepared for the first phases of the evolution of the postoperative diet (COSTA, 2013). Thus, preoperative nutritional education should promote the improvement of surgical outcome.

The psychological support provided to the patient who is a candidate for bariatric surgery (pre and post-operative) has some specific purposes (ROCHA; COSTA, 2012). Among them, we highlight the knowledge about eating habits, lifestyles, relationship with food and the emotions involved in these interactions (KORTCHMAR et al., 2018). After this knowledge, the psychologist becomes able to know and draw a continuity line from postoperative psychological follow-up, because the chances of achieving success with surgical treatment are higher (SILVA, 2015). Knowing the factors that can generate difficulties in this adaptation process, the patient is provided with greater safety and increased attention in these aspects that would place him within the risk range for weight gain (FAGUNDES; CAREGNATO; SILVEIRA, 2016).

Psychological support, therefore, is a way of knowing the factors that prevent the efficacy of post-bariatric treatment (MENSORIO, 2013). Given this scenario, clinical RC: 98479 
experience has pointed out that the success of surgical treatment of obesity does not depend only on the technical quality of the surgical procedure. It is a process, therefore, that depends on the patient's ability to adapt to a new dietary pattern, a new body and a new lifestyle (MAGDALENO JR; CHAIM; TURATO, 2009). Difficulties in drastically changing quality, as well as in the amount of what is ingested, can lead people who have undergone surgery not to lose weight or, if not all, of the weight lost (KORTCHMAR et al., 2018). This process can generate the feeling of failure and hopelessness, for this reason, psychological support is essential.

Long-term weight maintenance is essential (KULICK; HARK; DEEN, 2010). Another point to be evaluated is preoperative weight loss. There is insufficient evidence to support this weight loss prior to surgery, because when it is done, it promotes an unnecessary delay for the treatment of the patient (KIM et al., 2016). Studies claim that a preoperative low-calorie diet can cause certain pre-existing nutritional deficiencies, as well as loss of muscle mass can lead the patient to the risk of malnutrition, however, other studies understand that reducing abdominal and hepatic volume has better longterm results (EDHOLM et al., 2011; THIBAULT et al., 2016). In view of the present article, the present article has as a fundamental question: how do the strategies typical in the postoperative period promote greater care with diet and mental health in patients? To answer it, a literature review was carried out, with the objective of discussing the importance of post-bariatric psychological and nutritional follow-up.

\section{OBESITY AND ITS IMPLICATIONS}

Obesity significantly compromises quality of life and promotes predisposition to other non-communicable diseases, especially those that harm the mental health of the individual (MARTINS; MIYAZAKI, 2019). For this reason, obesity should be seen as a public health problem, considering that people's daily lives are compromised.

In order to make the context of this study better delimited, the implications of bariatric surgery, the multidisciplinary team that is part of this universe and the care provided by the psychologist and the nutritionist after surgery, it is necessary to understand the multifactoriality that involves obesity and, consequently, the bariatric patient RC: 98479 
(GORDON; KAIO; SALLET, 2011). Therefore, initially, it is a patient who needs psychological follow-up to be performed continuously, since the performance of this type of surgery requires a change of habit not only of the patient, but also of the social group of which he is part (KORTCHMAR et al., 2018).

It is noteworthy that family and interpersonal issues, relevant aspects of mental health, such as self-esteem, affective balance and perception of reality, and finally the followup by a multidisciplinary team are some of the terms that begin to integrate the life of the obese person, either before or after the surgical process (MARTINS; MIYAZAKI, 2019). Thus, it is necessary to understand, in this scenario, the social function assumed by the psychologist and the nutritionist and how essential its performance is.

The increased prevalence of overweight and obesity in the world has worried public health agencies, which has led to an increase in public spending. However, there is a plausible justification: efforts and willingness of funds are needed in numerous research projects dealing with the theme of obesity, as it increases significantly each year (RASOULI et al., 2007). The numbers are not typical of the Brazilian reality, since, due to certain eating habits and patterns, the numbers are high throughout the globe.

Nations such as Brazil, Canada and France deal with a high percentage of overweight individuals (about 40\%). Other countries, such as the USA and Germany, more than $65 \%$ of the population is classified in this way. In view of this scenario, it is understood that this social reality is reflected in the political-economic scenario, since an overload is created in health systems in a more significant way, that is, it is invested in preventive care, medical consultations, medications, hospitalizations, examinations, surgeries, among other possibilities (MARTINS; MIYAZAKI, 2019). Other indirect problems contribute to this increase, such as the absence of work, lost leisure time, morbidities and mortality (MELO, 2011). Kac; Sichieri and Gigante (2007) identified that it is less costly to treat obesity than to deal with the comorbidities that originate it. However, more effective and current preventive measures are required with treatment.

Such preventive measures, in order to be more efficient, should promote certain types of practices. Among them, there is a need to foster dialogue between the multiple RC: 98479 
complementary practices among themselves, especially those that involve the work of the psychologist and nutritionist jointly (GORDON; KAIO; SALLET, 2011). Obesity should be inserted in a dynamic context in which the disease exists, persists and creates mechanisms that start from poor diet, low energy expenditure, sedentary lifestyle and high caloric intake (MARTINS; MIYAZAKI, 2019). It is a medium that also needs to be treated and, thus, the population must be interpreted from an integral perspective, considering that they are inserted in a culture of consumption that must be reorganized. Therefore, habits that ensure collective well-being should be stimulated. In this context, bariatric surgery emerges and acts as a plausible alternative.

However, bariatric aby itself is not able to solve this public health problem that affects the quality of life of a number of people, not only from a local perspective, but globally. Therefore, psychological and nutritional follow-up is of paramount importance, and, therefore, one should invest in a health treatment that is based on a multidisciplinary approach (GONÇALVES; KOHLSDORF; PEREZ-NEBRA, 2020). The close monitoring of health professionals from multiple fields and the family itself are essential for the treatment to which the patient was submitted to be effective in the long term. Bariatric surgery is not restricted only to weight loss (FANDIÑO et al., 2004). It seeks, above all, the improvement in the biopsychosocial state of the individual, being an issue that permeates the quality of life (COSTA et al., 2009). Considering that the success of bariatric surgery depends, in addition to the multidisciplinary team, on the patient's motivation, which implies a change in living and consumption patterns (CAMPOS et al., 2016).

\section{THE CHARACTERISTICS OF BARIATRIC SURGERY}

Obesity reaches high peaks on a global scale, which has caught the attention of authorities, as well as requiring multiple efforts by increasingly multifaceted professionals and teams involved in its treatment, which includes physicians, nurses, psychologists, nutritionists and other health professionals (MARTINS; MIYAZAKI, 2019). Therefore, we seek alternatives that make the management of the disease more appropriate.

RC: 98479

Access link: https://www.nucleodoconhecimento.com.br/psychology/after-bariatric 
Bariatric surgery, in this context, is considered by many patients as the most effective way out of the effective fight against obesity. However, in the post-surgical period, it is necessary to maintain weight, since its benefits include, in addition to adjustment in body composition, a significant decrease in associated comorbidities (FLORES, 2014). Depressive and anxious symptoms are significantly reduced, as well as there is an improvement in sexual functioning, increased level of activity and integral improvement of health-related quality of life (FLORES, 2014).

In relation to the Brazilian context, the number of surgeries related to weight reduction has gradually increased, but expressively, which implies the need for greater attention to health and social well-being issues. To the detriment of the criticisms and controversies associated with bariatric surgery, it is recommended that the patient meet certain specific prerequisites before he can be submitted to it (GORDON; KAIO; SALLET, 2011). Depending on the patient's conditions, he may or may not become fit for the procedure. One of the parameters that allow this decision to be made is its follow-up by the multidisciplinary team, which also implies the presence of the family and the patient's own willpower to change habits and behaviors (FANDIÑO et al., 2004). Some comorbidities act as aggravating factors to non-aforego bariatric as an alternative to solving the problem.

Some examples can be cited, such as severe pneumopathy, renal failure, marked myocardial injury and liver cirrhosis (FANDIÑO et al., 2004). However, bariatric is generally well accepted and recommended. Regarding the recommendations for bariatric intervention, those related to the person and comorbidities stand out. In the early 1990s, the National Institute of Health of the United States began to emphasize the importance of the multidisciplinary approach in the preoperative period, including, in this process, the psychological evaluation prior to the operation, being an essential part and for decision making (FLORES, 2014). The Brazilian Bariatric Consensus and the Federal Council of Medicine also recommended this practice, but not without first determining the importance of the figure of a psychologist and/or a psychiatrist in the multidisciplinary team (COUTINHO, 1999). 
As the Federal Council of Medicine reiterates, the professional responsible, a priori, for the treatment of mental health, understood here as the psychologist and/or psychiatrist, is part of a team that assumes a fundamental responsibility. It aims to provide the patient with a better (critical) perception about their health status, which directly contributes to better treatment adem (ROSA et al., 2020). During the preoperative multidisciplinary evaluation, in addition to making a previous assessment of the history of personal and family health, the team should be concerned, among other things, with the practice/use or not of psychoactive substances, with the presence of psychotic or medical conditions, with the intellectual and cognitive level that allow the patient to be aware of the risks, successes and care related to the surgical process to which it will be submitted, such as preoperative care, and also attention should be paid to the aspects that influence the quality of life of patients and their families (FLORES, 2014).

In view of the above, it is necessary to discuss the classification of bariatric surgeries, which are: restrictive or disabsorptive.

Among the most common, there is vertical gastrectomy, also called Sleeve surgery, beinga restrictive surgery that removes much of the stomach (gastric bottom and body), leaving a residual stomach in the shape of a mango (linear tube) with volumetric capacity of $150 \mathrm{ml}$. Patients, with this procedure, experience an average reduction of $30 \%$ of total weight in the first 2 years (COUTINHO, 1999).

The Capella technique, known as gastric by-pass in $y$-Roux, consistsof a modality that gathers restriction to disabsorption. This is a gastroplasty associated with a gastrojejunal shunt in the form of the letter $\mathrm{Y}$ (called Roux $\mathrm{Y}$ ). The procedure reduces the size of the stomach so that it is able to adapt to a volume smaller than $30 \mathrm{ml}$ (MARTINS; MIYAZAKI, 2019). It also makes connection with a more distal intestinal loop (anastomosis), leading to an extensive disaborsotive area, since about 3 meters of slender are diverted from food transit (FANDIÑO et al., 2004).

The scopinaro technique, of a more dissorptive nature, is a method consisting of the application of a partial biliopancreatic "by-pass" with distal gastrectomy (FANDIÑO et RC: 98479 
al., 2004). Because it has a more malnourished capacity and is more dysabsorptive, this technique has been less performed than the Sleeve and Capella techniques.

The objective is not to point out the best procedure, but to list the existing possibilities and discuss about the benefits and ways that can cause the patient to have a better quality of life, since, among other things, the main scope is to contribute to weight reduction, contributing, in parallel, to improving the health of bariatric patients.

\section{THE IMPORTANCE OF NUTRITIONAL AND MENTAL FOLLOW-UP}

\subsection{NUTRITIONAL MONITORING}

Bariatric surgery is a procedure that adds positive results to the treatment of obesity and associated comorbidities. It is a subject that has long been discussed predominantly by physicians and nutritionists, but today part of an interdisciplinary approach, including psychology, psychiatry, endocrinology, anesthesiology, cardiology, physiotherapy, nursing and physical education (FAGUNDES; CAREGNATO; SILVEIRA, 2016). Given that these professionals are essential in the treatment (TRAVADO et al., 2004).

A study by Silva et al. (2015) sought to identify the profile of individuals who chose to perform bariatric surgery as an alternative to the treatment of obesity. It was concluded that, among the 100 interviewees, $49 \%$ stated that they had opted for surgery due to the failure of previous treatments; $39 \%$ to the detriment of associated diseases; and, finally, $12 \%$ opted for the procedure due to its efficiency and ease in the loss of excess weight (SILVA et al., 2015).

The objectives that motivated patients to seek bariatric surgery indicate that $87 \%$ chose to desire a better quality of life; $82 \%$ to improve health; $34 \%$ for aesthetic factors; and $15 \%$ for social factors (SILVA et al., 2015). Patients who underwent six months of preoperative nutritional follow-up had a greater weight reduction than those who preoperatively stopped losing weight or regained lost weight (KORTCHMAR et al., 2018). In view of this scenario, it is hypothesized that a longer time of nutritional follow-

RC: 98479

Access link: https://www.nucleodoconhecimento.com.br/psychology/after-bariatric 
up for patients who are candidates for bariatric surgery can demote them, which could justify the results found by the two studies. In this sense, the information provided by the nutritionist professional can promote new eating habits, which increases the chances of success of the surgery (ARAGÃO; ZAMBON, 2021).

The frequency with which these patients have consultations with nutritionists is a decisive factor for the success of the surgery. Those who undergo this follow-up have greater loss of excess weight after surgery (BARDAL; CECCATTO; MEZZOMO, 2016). Weight recurrence was observed in $39 \%$ of patients submitted to reducing gastroplasty, especially from 12 months after the surgical procedure. Regarding preoperative weight loss, $74 \%$ of the patients presented weight loss without nutritional follow-up, which justifies the relevance of this professional in the postoperative period (BARDAL; CECCATTO; MEZZOMO, 2016). Weight reduction in the preoperative period is beneficial, as it boosts the patient's adhering to healthier habits, since it will be more conditioned to an adequate diet after the procedure. However, on the other hand, weight reduction from unfounded methods, such as dietary restriction and lowcalorie diet without nutritional follow-up, are some of the aspects that can cause situations of nutritional deficiencies common in obese patients (RODRIGUES; FARIA, 2020). This is the case of vitamin $D$ and iron profile in women of childbearing age (RODRIGUES et al., 2017).

Another factor that should be considered in the evaluation is the reduction of muscle mass due to a severe caloric restriction. This can cause disorders in functional capacity, reduced protein synthesis and decreased immune competence (BONAZZI et al., 2007). In addition, the preoperative weight reduction is based on the transoperative ease for the surgeon in which there is a reduction in intra-abdominal fat and a reduction in liver volume, which, in most patients who desire surgery, is affected by hepatic satatosis. Other studies understand that weight reduction greater than $9.5 \%$ more significantly reduces complications compared to weight loss below $5 \%$ in patients with $\mathrm{BMl}$ greater than $45 \mathrm{~kg} / \mathrm{m}^{2}$. Patients with $\mathrm{BMl}>50 \mathrm{~kg} / \mathrm{m}^{2}$ may benefit the most in terms of surgical technique (THIBAULT et al., 2016). 
The objective of nutritional follow-up before surgery is to raise awareness about the importance of adhering to healthy eating habits, essential for maintaining long-term post-surgical weight loss (GONÇALVES; KOHLSDORF; PEREZ-NEBRA, 2020). In view of this scenario, knowledge about food and nutrition in individuals submitted and candidates for bariatric surgery raises some frequent doubts, such as the possibility of vomiting, satisfaction in the first 48 hours after surgery, possible changes in taste and depressive conditions, which further reinforces the importance of the multidisciplinary team's performance (NISHIYAMA et al., 2007). A study revealed the expressive impact of interdisciplinary follow-up on the efficacy of bariatric surgery and demonstrated that it is of vital importance to prepare the individual before performing the surgery (MASARI et al., 2012).

The eating behavior of obese people is related to the environment in which the individual lives. Inadequate eating habits acquired throughout childhood corroborate increased body adiposity (NISHIYAMA et al., 2007). Moreover, there is a worsening in quality of life in overweight individuals, since there is a greater chance of developing comorbidities associated with obesity. Thus, nutritional interventions related to nutritional education practices also contribute to the improvement of quality of life (BATISTA FILHO; RISSIN, 2003). A study that compared eating behavior with the preference of individuals in the pre and postoperative period of bariatric surgery found that, of patients in preoperative preparation, $94 \%$ had a "pinching behavior". Of the patients submitted to surgery, $60 \%$ had this same behavior (MACHADO et al., 2008).

Among the patients submitted to this surgical procedure, 33.3\% acquired better eating habits after surgery and $63 \%$ remained with the same habits identified before surgery, which further reinforces the importance of nutritional follow-up (RODRIGUES et al., 2017). Before surgery, patients had a preference for high-calorie foods, such as simple carbohydrates (42\%), sweets (26\%) and snacks (14\%) (MACHADO et al., 2008). However, after surgery, the study found that patients searched for easily intaked foods, such as sweets $(45 \%)$, snacks $(22 \%)$, carbohydrates $(20 \%)$ and increased preference for beer (7\%) (MACHADO et al., 2008). The frequency of binge eating episodes by patients preoperatively increased due to increased nervousness, which was an 
imbalance factor that stimulated excess food intake and $24 \%$ reported the presence of anxiety and/or mood disorders (depression).

Obese compulsive individuals have a greater predisposition to become "pinchers" after bariatric surgery, since the preference for the consumption of sweets and snacks is higher in compulsive obese than in non-compulsive obese individuals (COLLES; DIXON; O'BRIEN, 2008). "Pinching" habits and eating compulsion themselves remain or are enhanced after the procedure, which further demonstrates the importance of psychological and/or psychiatric and nutritional follow-up in the pre- and postoperative periods, since inadequate habits can contribute to weight gain in these patients. These may be related to the higher prevalence of gastrointestinal symptoms, dumping syndrome, as well as may cause severe psychological damage (FLORES, 2014; MACHADO et al., 2008; GREENBERG; SOGG; PERNA, 2009). The act of eating is intrinsically linked to internal and external stimuli.

Organic, psychic and social factors are considered, and thus, it is perceived that food intake moves beyond nutritional aspects, and thus reconciles the hidden motivations related to conflicts experienced and that are independent of the feeling of hunger (MACHADO et al., 2008; SOUTO; FERRO-BUCHER, 2006). The limitation caused by bariatric surgery can cause risks to compulsive individuals, which may hinder their adaptation to the new food state, since gastric capacity will be lower, and thus will bring harm if the individual continues to feed incorrectly (BOCCHIERI-RICCIARDI et al., 2006). Individuals who are candidates for bariatric surgery understand the dynamics associated with binge eating. The search for new habits is a way to ensure that new disorders will not prevail after the procedure. Nutritional guidelines should be clarified to the patient.

Topics of extreme importance should be addressed in so that post-surgical success is noticed, such as digestion and absorption of nutrients before and after the procedure; guidelines on the preparation of healthier dishes; reading industrialised food labels; purchases in the market; and, finally, these candidates should be instructed on feeding during the first months after surgery (BOCCHIERI-RICCIARDI et al., 2006). The importance of the nutritionist during the entire follow-up in the pre and postoperative RC: 98479 
period becomes summary. In order to achieve positive results. Preoperative evaluation should be strictly followed, based on a previously elaborated activity protocol. It is necessary that the patient and the interdisciplinary team are involved and aware about the importance of promoting healthier eating habits (MASARI et al., 2012).

\subsection{MENTAL HEALTH FOLLOW-UP}

Psychological aspects can influence or be a consequence of obesity, as well as may be responsible for weight gain or difficulties in maintaining the weight reached after surgery (VACCARO, 2018). Cases of failure to maintain weight loss are also associated with the feeling of lack of preparation for the necessary changes. Avoiding the failure of bariatric treatment depends on a pre-surgical investigation on the patient's history with food, on the role of food in his life, as well as it is necessary to investigate and take care of the impulse that leads to the voracity of eating (EDLER, 2017). Surgery is capable of slimming down the body, however, some psychological problems can be neglected, and they are related to diet control, self-esteem and coping with eating linked to emotion, which implies creating an identity with the body, a new challenge, because self-assessment, after weight loss, is negative (FAGUNDES; CAREGNATO; SILVEIRA, 2016).

This negative construction is associated with body image, excess skin, perception of the self in the new body and adaptation and reconstitution and self-image in the lean body (ALEGRÍA; LARSEN, 2013). Follow-up and psychological support before and after surgery contributes to the improvement of patients' results in their challenge to lose weight, to gain a higher quality of life and to reduce the desire to eat, being these crucial factors to avoid the recurrence of obesity (HOLLYWOOD; OGDEN; PRING, 2012). There are also associated reduction of hunger, the slightest concern with food, as well as the feeling of greater control regarding food intake.

One study detected that the type of coping adopted by the patient after bariatric surgery determines or not the result of weight loss, and that psychological and physiological factors combine and interact significantly, thus influencing the results (the construction of a more positive image on the body, for example) (FIGURA et al., 2015).

RC: 98479

Access link: https://www.nucleodoconhecimento.com.br/psychology/after-bariatric 
The operated individuals can go through a period of emotional restructuring, a phase in which it is essential to maintain psychological follow-up, through therapies, to avoid cognitive distortions and perceptions about deformed reality. (MAGDALENO JR.; CHAIM; TURATO, 2008). In view of this scenario, attention is drawn to the need for individualized psychological treatment in the pre- and post-surgical period. It is linked to the identification and treatment of the mental structure of each patient, aiming, with these care, to avoid further complications after surgery (GORDON; KAIO; SALLET, 2011). The physical, psychological, social and clinical experiences of patients undergoing bariatric surgery influence the treatment process. Among those that most affect these subjects are: physical changes and subsequent challenges, psychological experiences, social support and clinical experiences (LIU; IRWIN, 2017).

There is improvement in psychological, physical and social conditions, however, there is a continuous concern about possible unforeseen events typical of the results of surgery and the importance of supporting the health services recommended for the post-surgical period, including, in this process, psychological support, since patients need to learn how to deal with changes in the body, social relations and the construction of a new identity (LIU; IRWIN, 2017). The relatives or caregivers of the bariatric patient also need psychological support (SPRENGEL, 2015), since social support to all involved implies a better adhering to healthier health behaviors, such as physical activity, ahealthier eating, reduction of stress situations (MARTINS; MIYAZAKI, 2019). Thus, health improvement is promoted, including mental health and quality of life (ABREU RODRIGUES; SEIDL, 2015).

However, the efficacy of treatment requires some care, such as the time of psychological preparation before and after surgery, both for the patient and for the spouses and family members, since they are the ones who will accompany them throughout the pre- and post-bariatric treatment (DELAPRIA, 2019). Motivation and long-term patient support should be stimulated in the psychological follow-up process (MARCHESINI, 2010). In this journey, including both family and friends in the preoperative process is of paramount importance, as well as ensuring the patient's clarity regarding the gains and losses involved in the procedure (VACCARO, 2018).

RC: 98479

Access link: https://www.nucleodoconhecimento.com.br/psychology/after-bariatric 
The treatment, therefore, requires the performance of a multidisciplinary team. This should understand the subjectivity of each case, foreseeing and accompanying those factors that, directly or indirectly, can influence the success or failure of the process, which implies resizing certain strategies to achieve success (MARCELINO; PATRíCIO, 2011).

Bariatric surgery, in fact, offers a higher quality of life to the patient, as well as promotes the improvement of socialization due to weight loss, however, it should be emphasized that, in this treatment process, the patient will still have to deal with psychic and nutritional issues in order to reach the desired quality of life (DELAPRIA, 2019). Support is essential so that changes in eating behavior and lifestyle can be made possible, as well as body, social and identity changes (VACCARO, 2018). The maintenance and continuity of weight due to surgical treatment depend on the patient's action, awareness and commitment, which can be difficult and unfeasible without psychological and nutritional follow-up.

The patient himself must realize that he is the transforming agent. Surgery slims down, but the lean body depends on internal changes, a demand that goes beyond the stomach. The adaptation to the new dimensions of the body and the adjustment in social relations, as well as the construction of a new identity and the disconnection of the impulse to eat are issues that may arise after the surgery, and thus require greater attention and care (GORDON; KAIO; SALLET, 2011). Psychotherapy can contribute to the mind following the body's slimming process.

\section{FINAL CONSIDERATIONS}

This study aimed to demonstrate the importance of nutritional and mental follow-up before and after bariatric surgery. The evidence indicates that the role played by the psychologist in the multidisciplinary team, especially in the postoperative period of bariatric patients, with regard to the control and/or reduction of anxiety and depressive symptoms, and other psychopathological changes that harm mental health, is essential, which makes the debate about the role of psychologists and other professionals involved fundamental. The relevance of these professionals is tied to the RC: 98479 
fact that a multidisciplinary action will make the patient submitted to bariatric get used to a new standard of living (eating habits, relationship with food and the body) and, in this process, psychological follow-up during the pre and postoperative period is relevant to avoid problems such as weight gain.

The psychological evaluation of bariatric patients is relevant, because, in this way, it is possible to understand this patient holistically, and, thus, a reduction in mental complications from surgery that can impair the patient's quality of life is promoted. The need for an in-depth psychological assessment becomes summary. The patient should be investigated and educated so that successive changes to surgery are effective and visualized in the long term. The indications and contraindications related to bariatric surgery should respect the evaluation of the multidisciplinary team, considering that, due to the collections and pressures of day-to-day, problems affecting mental health, such as anxiety disorders, such as anxiety disorders, among them stand out social phobia, generalized anxiety and panic disorder, in relation to mood disorders, the increasing number of people affected by depression is worrying.

Such disorders have become frequent and plague the lives of many individuals. It is in the midst of this process, in a way, turbulent, that the post-bariatric patient is found, this has to deal, almost always, with an emotional burden beyond the bearable, which ends up creating unexpected disorders associated with anxiety. In this sense, the psychologist plays a very important role since the beginning of the surgical process, but his performance is not restricted to him. Therefore, its contribution in the postoperative period is essential.

\section{REFERENCES}

ABREU-RODRIGUES, M.; SEIDL, E. M. F. Apoio social e reganho de peso póscirurgia bariátrica: estudo de caso sobre intervenção com cuidador. Temas em Psicologia, v. 23, n. 4, p. 1003-1016, 2015. 
AILLS, L. et al. ASMBS allied health nutritional guidelines for the surgical weight loss patient: surgery for obesity and related diseases. Surg Obes Relat Dis., v. 4, n. 5, p. 73-108, 2008.

ALEGRÍA, C. A.; LARSEN, B. "That's who I am: A fat person in a thin body": Weight loss, negative self-evaluation, and mitigating strategies following weight loss surgery. Journal of the American Association of Nurse Practitioners, v. 27, n. 3, p. 137144,2013

ARAGÃO, C. N.; ZAMBON, E. A avaliação psicológica para cirurgia bariátrica - uma análise teórica e prática. Rumos da inFormação, v. 2, n. 1, p. 63-76, 2021.

BARDAL, A. G.; CECCATTO, V.; MEZZOMO, T. R. Fatores de risco para recidiva de peso no pós-operatório tardio de cirurgia bariátrica. Scientia médica, v. 26, n. 4, p. ID24224-ID24224, 2016.

BATISTA FILHO, M.; RISSIN, A. A transição nutricional no Brasil: tendências regionais e temporais. Cadernos de saúde pública, v. 19, p. S181-S191, 2003.

BOCCHIERI-RICCIARDI, L. E. et al. Pre-surgery binge eating status: effect on eating behavior and weight outcome after gastric bypass. Obesity surgery, v. 16, n. 9, p. 1198-1204, 2006.

BONAZZI, C. L. et al. A intervençâo nutricional no pré e pós operatório da cirurgia bariátrica. RBONE-Revista Brasileira de Obesidade, Nutrição e Emagrecimento, v. 1 , n. 5, p. 59-69, 2007.

BRASIL. Ministério da Saúde. Vigitel 2016: vigilância de fatores de risco e proteção para doenças crônicas por inquérito telefônico. Brasília: Ministério da Saúde, 2017.

BUCHWALD, $\mathrm{H}$. et al. Bariatric surgery: a systematic review and meta-analysis. Jama, v. 292, n. 14, p. 1724-1737, 2004. 
CAMPOS, J. et al. O papel da cirurgia metabólica para tratamento de pacientes com obesidade grau ie diabete tipo 2 não controlados clinicamente. ABCD: Arquivos Brasileiros de Cirurgia Digestiva (São Paulo), v. 29, p. 102-106, 2016.

COLLES, S. L.; DIXON, J. B.; O'BRIEN, P. E. Loss of control is central to psychological disturbance associated with binge eating disorder. Obesity, v. 16, n. 3, p. 608-614, 2008.

COOPER, P. L. et al. Nutritional consequences of modified vertical gastroplasty in obese subjects. International journal of obesity, v. 23, n. 4, p. 382-388, 1999.

COSTA, A. C. C. et al. Obesidade em pacientes candidatos a cirurgia bariátrica. Acta Paulista de enfermagem, v. 22, p. 55-59, 2009.

COSTA, D. Eficiência do acompanhamento nutricional no pré e pós-operatório da cirurgia bariátrica. RBONE-Revista Brasileira de Obesidade, Nutrição e Emagrecimento, v. 7, n. 39, 2013.

COUTINHO, W. Consenso latino-americano de obesidade. Arquivos Brasileiros de Endocrinologia \& Metabologia, v. 43, n. 1, p. 21-67, 1999.

DELAPRIA, A. M. T. A importância do acompanhamento psicológico no pré e pósoperatório da cirurgia bariátrica. Revista UNINGÁ, v. 56, n. S1, p. 78-88, 2019.

DOLNE, F.; SOUZA, J. S. M. de.; MATTE, J. Atuação da enfermagem na assistência prestada ao paciente obeso mórbido no pós-operatório de cirurgia bariátrica. RBONERevista Brasileira De Obesidade, Nutrição E Emagrecimento, v. 14, n. 87, p. 550559, 2020.

EDHOLM, D. et al. Preoperative 4-week low-calorie diet reduces liver volume and intrahepatic fat and facilitates laparoscopic gastric bypass in morbidly obese. Obesity surgery, v. 21, n. 3, p. 345-350, 2011.

EDLER, S. Tempos Compulsivos: a busca desenfreada pelo prazer. Rio de Janeiro: Casa da Palavra, 2017. 176 pgns.

RC: 98479

Access link: https://www.nucleodoconhecimento.com.br/psychology/after-bariatric 
FAGUNDES, M. A. B. G.; CAREGNATO, R. C. A.; SILVEIRA, L. M. de. O. B. Variáveis psicológicas associadas à cirurgia bariátrica. Aletheia, v. 49, n. 2, p. 47-54, 2016.

FANDIÑO, J. et al. Cirurgia bariátrica: aspectos clínico-cirúrgicos e psiquiátricos. Revista de psiquiatria do Rio Grande do Sul, v. 26, n. 1, p. 47-51, 2004.

FIGURA, A. et al. Determinants of weight loss following laparoscopic sleeve gastrectomy: the role of psychological burden, coping style, and motivation to undergo surgery. Journal of obesity, v. 2015, p. 1-10, 2015.

FLORES, C. A. Avaliação psicológica para cirurgia bariátrica: práticas atuais. ABCD: Arquivos Brasileiros de Cirurgia Digestiva (São Paulo), v. 27, p. 59-62, 2014.

GONÇALVES, S. J. B. G.; KOHLSDORF, M.; PEREZ-NEBRA, A. R. Adesão ao pósoperatório em cirurgia bariátrica: análise sistemática da literatura brasileira. Psicologia Argumento, v. 38, n. 102, p. 626-646, 2020.

GORDON, P. C.; KAIO, G. H.; SALLET, P. C. Aspectos do acompanhamento psiquiátrico de pacientes obesos sob tratamento bariátrico: revisão. Archives of Clinical Psychiatry (São Paulo), v. 38, p. 148-154, 2011.

GREENBERG, I.; SOGG, S.; PERNA, F. M. Behavioral and psychological care in weight loss surgery: best practice update. Obesity, v. 17, n. 5, p. 880-884, 2009.

HOLLYWOOD, A.; OGDEN, J.; PRING, C. The impact of a bariatric rehabilitation service on weight loss and psychological adjustment-study protocol. BMC Public Health, v. 12, n. 1, p. 1-5, 2012.

KAC, G.; SICHIERI, R.; GIGANTE, D. P. Epidemiologia nutricional. São Paulo: Editora Fiocruz, 2007. 580 pgns.

$\mathrm{KIM}$, J. et al. ASMBS updated position statement on insurance mandated preoperative weight loss requirements. Surgery for Obesity and Related Diseases, v. 12, n. 5, p. 955-959, 2016.

$\mathrm{RC}: 98479$ 
KORTCHMAR, E. et al. Reganho de peso após a cirurgia bariátrica: um enfoque da fenomenologia social. Acta Paulista de Enfermagem, v. 31, n. 4, p. 417-422, 2018.

KULICK, D.; HARK, L.; DEEN, D. The bariatric surgery patient: a growing role for registered dietitians. Journal of the American Dietetic Association, v. 110, n. 4, p. 593-599, 2010.

LIU, R. H.; IRWIN, J. D. Understanding the post-surgical bariatric experiences of patients two or more years after surgery. Quality of Life Research, v. 26, n. 11, p. 3157-3168, 2017.

MACHADO, C. E. et al. Compulsão alimentar antes e após a cirurgia bariátrica. ABCD: Arquivos Brasileiros de Cirurgia Digestiva (São Paulo), v. 21, p. 185-191, 2008.

MAGDALENO JR, R.; CHAIM, E. A.; TURATO, E. R. Características psicológicas de pacientes submetidos à cirurgia bariátrica. Revista de Psiquiatria do Rio Grande do Sul, v. 31, p. 73-78, 2009.

MAGDALENO JR, R.; CHAIM, E. A.; TURATO, E. R. Psychological characteristics of patients submitted to bariatric surgery. Revista de Psiquiatria do Rio Grande do Sul, v. 31, p. 73-78, 2009.

MARCELINO, L. F.; PATRICIO, Z. M. A complexidade da obesidade e o processo de viver após a cirurgia bariátrica: uma questão de saúde coletiva. Revista Ciência e Saúde Coletiva, v. 16, n. 12, p. 4767-4776, 2011.

MARCHESINI, S. D. Late psychological follow-up on patients submitted to bariatric surgery. ABCD: Arquivos Brasileiros de Cirurgia Digestiva, v. 23, n. 2, p. 108-113, 2010.

MARTINS, C. E. P.; MIYAZAKI, E. T. A presença do psicólogo na equipe multidisciplinar e a ansiedade pós-cirurgia bariátrica. Revista Campo do Saber, v. 5, n. 2, p. 77-90, 2019. 
MASARI, S. P. et al. Preparação multidisciplinar pré-cirúrgia bariátrica na visão do cliente. RBONE-Revista Brasileira de Obesidade, Nutrição e Emagrecimento, v. 6, n. 32, p. 1-13, 2012.

MELO, M. E. Os Números da Obesidade no Brasil: VIGITEL 2009 e POF 20082009. 2011. Disponível

em: https://www.saudedireta.com.br/docsupload/1340368729Obesidade\%20no\%20Brasil \%20VIGITEL\%202009\%20POF2008_09\%20\%20II.pdf. Acesso em: 02 ago. 2021.

MENEGOTTO, A. L. S. et al. Avaliação da frequência em consultas nutricionais dos pacientes após cirurgia bariátrica. ABCD: Arquivos Brasileiros de Cirurgia Digestiva (São Paulo), v. 26, p. 117-119, 2013.

MENSORIO, M. S. Análise de estratégias de enfrentamento, ansiedade e hábitos em pacientes elegíveis à cirurgia bariátrica, com e sem acompanhamento psicológico. 2013. 159f. Dissertação (Mestrado em Processos de Desenvolvimento Humano e Saúde) - Universidade de Brasília, Brasília, DF, 2013.

NISHIYAMA, M. F. et al. Avaliação do nível de conhecimento e aderência da conduta nutricional em pacientes submetidos e candidatos à cirurgia bariátrica. Arquivos de Ciências da Saúde da UNIPAR, v. 11, n. 2, p. 89-98, 2007.

RASOULI, N. et al. Ectopic fat accumulation and metabolic syndrome. Diabetes, Obesity and Metabolism, v. 9, n. 1, p. 1-10, 2007.

ROCHA, C.; COSTA, E. Aspectos psicológicos na obesidade mórbida: Avaliação dos níveis de ansiedade, depressão e do auto-conceito em obesos que vão ser submetidos à cirurgia bariátrica. Analise psicológica, v. 30, n. 4, p. 451-466, 2012.

RODRIGUES, G. et al. Acompanhamento nutricional no pré-operatório de cirurgia bariátrica: tempo de seguimento versus redução de peso. Revista PsicoFAE: Pluralidades em Saúde Mental, v. 6, n. 2, p. 97-112, 2017. 
RODRIGUES, J. O.; FARIA, H. M. C. Os aspectos psicossociais da cirurgia bariátrica: do pré ao pós-operatório. Cadernos de Psicologia, v. 2, n. 4, p. 551-569, 2020.

ROSA, T. M. F. et al. Atendimento nutricional em grupo de pacientes candidatos a cirurgia bariátrica: repercussões no consumo alimentar. RBONE-Revista Brasileira De Obesidade, Nutrição E Emagrecimento, v. 14, n. 87, p. 690-698, 2020.

SILVA, M. A da. Emagrecimento induzido por cirurgia: ação do psicólogo após a cirurgia bariátrica. Bol. Psicol., v. 65, n. 143, p. 243-246, 2015.

SILVA, P. T. da. et al. Perfil de pacientes que buscam a cirurgia bariátrica. ABCD: Arquivos Brasileiros de Cirurgia Digestiva (São Paulo), v. 28, p. 270-273, 2015.

SOCIEDADE BRASILEIRA DE CIRURGIA BARIÁTRICA E METABÓLICA (SBCBM). 2017. Disponível em: http://www.sbcbm.org.br/. Acesso em: 02 ago. 2021.

SOUTO, S.; FERRO-BUCHER, J. S. N. Práticas indiscriminadas de dietas de emagrecimento e o desenvolvimento de transtornos alimentares. Revista de Nutrição, v. 19, p. 693-704, 2006.

SPRENGEL, A. L. Cirurgia Bariátrica: Manual de instruções para pacientes e familiares. São Paulo: M. Books do Brasil, 2015. 96 pgns.

THIBAULT, R. et al. Twelve key nutritional issues in bariatric surgery. Clinical nutrition, v. 35, n. 1, p. 12-17, 2016.

TRAVADO, L. et al. Abordagem psicológica da obesidade mórbida: Caracterização e apresentação do protocolo de avaliação psicológica. Análise psicológica, v. 22, n. 3, p. 533-550, 2004.

VACCARO, R. V. Acompanhamento psicológico e manutenção da perda de peso após a cirurgia bariátrica do tipo Bypass. 2018. 81f. Dissertação (Mestrado em Psicologia Clínica) - Pontifícia Universidade Católica de São Paulo, São Paulo, SP, 2018

RC: 98479 
Enviado: Outubro, 2021.

Aprovado: Outubro, 2021. 